\title{
The Implementation of Assessment Character Education Results in Secondary School
}

\author{
Gendon Barus \\ Sanata Dharma State University, Yogyakarta \\ Corresponding e-mail: bardon.usd@gmail.com
}

\begin{abstract}
Integrated character education in secondary school (SMP) has been planned and conducted since 2010, but the result is not yet optimal and there is a lot of obstacle in conducting the plan. The weak monitoring from the government toward this integrated character education, not all guidance and counseling teacher have time to enter class to give the appropriate character guidance, class teacher that forced to be a character educator in between class time, and the lack of character education process and result assessment/evaluation system are factors that support the unsuccessful implementation of integrated character education in school. The character education problem that occur in SMP need to be assessed in order to found the alternative solution, and also need to develop an effective and operational evaluation model for character education process and result so it become easy to implement in school. Yet, the government haven't developed a standardize assessment, measurement, and evaluation system for character education to evaluate the integration character education process and result in SMP. Common way is used by teacher to assess students' character education in school and it still focused on using the technique of observation, behavior scale, and point system. That method has a lot of disadvantages such as subjective, sporadic, perceptional, inconsistent, less systematic and draw many arguments. How does the character education process and result in SMP assessed and what is the obstacle? This article is intended to discuss those based on the findings of evaluative research at 11 SMPs from some city in Indonesia. The data was collected through closed-opened questioner from 51 principals and teachers during June 2017. The data was analyzed in simple way; descriptive explorative using percentage technique and the result presented in graphical perspective.
\end{abstract}

Keyword: $\quad$ assessment, character education in secondary school (SMP), observation, Indonesia

\section{INTRODUCTION}

The character education movement becomes hit after launched since 2010, but it's assessment and evaluation do not talk much. According to Ministry of National Education (2010), character is related to personal nature, behavior, moral, or personality that developed from internalitation of various virtues that believed and used as the basis of that person perspective, thought, attitude and action. Character makes person has a unique characteristic that differ from other. Character is identical with moral, nature (Suparno, 2013), thought, and attitude that different in each individual for their life and cooperation with other (Samani and Hariyanto, 2013:41), based on that, character is human universal behavior values that cope all human activities related to God, him/herself, others, and also the environment which showed in the thought, attitude, feeling, words, and action based on religion, law, politeness, culture, and indigenous law norms. Then character is described as" ...an individuals pattern of behavior...his moral constitution ..." (Bohlin, 2003). How to assess it? It is not an easy job, even though every learning process should be related to measurement and assessment (Marzano, Pickering, and McTighe, 1993).
Assessment issues arise when school is preparing reports on student learning outcomes. In both numerical and words evaluations scale, the reports are generally less accurate in describing the fact. For example, if it is stated that the Character Building value is $80 \%$, what character qualities are implied by that number, and what is the difference with the $70 \%$ ? If declared in the report the learning result value is B or good, what quality of the learner's character is considered good? That sometimes makes Character Building lessons less meaningful to students. (Setyawan, 2014)

Another problem that faced by teachers in character assessment is the less ideal of teachers and students' ratio. The number of students to be taught and the short study hours leads to the careless observation and assessment of student characters. Most of the value must be taken from the direct observation results in the classroom with a limited time and too many students. Measurement and assessment of student performance requires considerable time and requires students to construct new knowledge (Marzano, Pickering, and McTighe, 1993:26). Then, it is recommended that the recording of student performance is done continuously. Ongoing or continuous recording is done by the teacher in the context of student observation in the class. The teacher observes and the students know 
what is observed. Observation on student performance are not only limited to what is done in the classroom, but also outside the classroom.

Morals or character is abstract in nature. But even though it is abstract, one's character can be known by others through living together in a certain time or through an observation. As a lesson material, teachers must make operational definitions and indicators to measure and then evaluate the character of the student. The problem is that teachers experience difficulties because the observations are based on principles that are still abstract and have not been described in operational definitions and indicators. Assessment without a clear indicator will only entrap the teacher into " approximately value " with a very high element of subjectivity and often leads teachers into like and dislike opinion, a dishonest and unfair judgment. In Character Building lessons, the most important thing to do is observation. However, observation has a problem; high subjectivity. The main problem with observation is the lack of observer objectivity (Johnson and Johnson, 2002:117). Observation is a more appropriate way to measure the performance of characters at the action level rather than the use of rating scale that is perceptive and cognitive. Is observation really reliable as a way of assessing student character?

Gibson \& Mitchell (2011:389), Mc. Millan \& Schumacher (2001:276) pointed out some of the following observational weaknesses: First, the human ability to accurately store the impressions obtained from observations is very limited, both in numbers and duration of impression (information). Consequently, there is something that may be missing or incomplete. Gibson \& Mitchell (2011:389) noted that not many people are able to save a very broad and detailed impression. Therefore, observers need an observation tool. A researcher who observes a number of students in a class will have difficulty in storing information on how many children are in the class, how many boys are there and how many girls, who sits near who, and what color is the dresses. Especially, if only the information must be stored for a long time.

Second, the individual's perspective on the same object is not always the same, because everyone has a unique frame that may be different from one another. As a result, the impression is also not the same and the assessment is not the same. Gibson \& Mitchell (2011: 390) showed that observations are strongly influenced by adaptability, habits, desires, prejudices, and projections.

Third, a person's impression of an object is also not always the same. Consequently, the interpretation and judgment given to the same object are not the same. Someone who upholds social norms, when seeing a teenager with colorful hair colored and wearing earrings, maybe he/she will have the impression that the teenager is naughty. But for other observers who are easy to accept new values will have a different impression, maybe he/she view the teenager's appearance is up to date, even he/she assessed it as positive.

Fourth, there is a tendency for humans to judge something too high or too low based on a prominent trait. An observer in assessing a student is sometimes still influenced by who he is, or judging by consideration of something that has nothing to do with the aspect that being assessed. Sometimes people provide an assessment of someone by seeing how he/she looks, although the appearance sometimes does not describe the real reality.

Another difficulty in conducting the student character assessment is the scope of the objectives and substance of character education itself. Ministry of National Education/MoNE (2011:7) asserted that character education goal is to develop values that shape the character of the nation which is Pancasila, include: (1) Developing the learners potential to be good-hearted, good minded, and well-behaved, (2) Build the national character Pancasila, (3) Developing citizens' potential to have selfconfidence, pride in their nation and country, and humanity love. The formulation of such goal is very abstract and not easily measured because it involves the formulation of non-operational indicators.

At junior high school (secondary school/SMP) level, 20 main character values were extracted from SMP's Student's Competency Standards items (MoNE Policy No. 23 Year 2006) and Competency Standards/Basic Competency (MoNE Policy No. 22 Year 2006). The 20 selected character values are still very global and common. The teacher's task is make it operational so the teachers can assess appropriately, honestly, comprehensively, and equitably. Of course, this job is not easy for any teacher, let alone the nature of affective and moral acting. The government in this case does not provide enough concrete boundary/framework.

Suyanto (2010: 9), asserted that the success of character education program can be known primarily through the achievement of Passing Competency Standards of students which include: (1) Implement the religious teachings adopted according to the stage of adolescent development, (2) Understanding the shortcomings and advantages (3) Showing confidence (4) Obey the prevailing social rules in the wider environment, (5) Appreciate the diversity of religion, culture, ethnicity, race, and socioeconomic groups within the national scope, (6) Find and implement information from the society and other source in logical, critical, and creative way, (7) Demonstrate logical, critical, creative, and innovative thinking ability, (8) Demonstrate self-learning ability in accordance with its potential, (9) Demonstrate the ability to analyze and solve problems in everyday life, (10) Describe natural and social phenomena, (11) Utilize the environment in responsible way, (12) Applying the values of togetherness in the life in 
society, and nation for the unity, (13) Appreciate the work of art and national culture, (14) Appreciate the work task and have the ability to work, 15) Implementing clean, healthy, fit, and safe life and utilizing leisure time, (16) Communicating and interacting effectively and courteously, (17) Understanding the rights and obligations of self and others in the community; (19) Demonstrated listening, speaking, reading and writing skills in simple Indonesian and English, (20) Mastering the knowledge required to attend secondary education, and (21) Has an entrepreneurial spirit. How to assess the achievement of all these indicators comprehensively? Again, the teacher does not have sufficient time to look at this in depth while teaching a substantial subject matter study as his primary duty.

At the school level, the criterion for attaining character education is the formation of school culture. The meaning of school culture is daily behavior, traditions, daily habits, and symbols practiced by all member of the school, and surrounding communities that must be based on these values. How to evaluate it? Who is assigned to observe and measure the achievement of the characteristics of cultured schools? Godwin and Godwin (Didith, et al., 2014:53) described the assessment as a process of determination, through observation and testing of, the individuals' nature or behavior, the program characteristics or properties of some other entities and then assigning a rating or score. According to Griffin and Nix (1991) assessment is a statement based on a number of facts to explain the characteristics of a person or something. Linn and Grounlund (Uno and Koni, 2012:1) asserted that assessment is a process that undertaken to obtain information used in order to make decisions about learners, curricula, programs, and educational policies, methods and or educational instruments by an agency which organizes a certain activity. Given the strategic role of character education assessment data, the state (government) should be present and not just give the assessment work to the school, especially to the teachers themselves, which obviously they are not specially prepared as "teachers and assessors". Based on the various facts and problems of the character results assessment difficulty stated above, this simple study intends to get an idea of what the nature of the character education outcomes assessment in SMP.

\section{METHODS}

This research is descriptive quantitative study at explorative level. The description explored concerns on how the character education outcomes assessment among junior high school (SMP) teachers is assessed. How the teachers understand the urgency of assessing the outcomes of character education in schools, how assessments are planned and implemented, what techniques and instruments are used in the assessment of character outcomes. The subjects were 51 teachers from 11 junior high schools spread across several cities in Indonesia: 1) SMP N 7 Pangkalpinang, Bangka Belitung, 2) SMP N 1 Gedungaji, Tulangbawang Lampung, 3) SMPK Frater Xaverius 1 Palembang, 4) SMP N 7 Cirebon, West of Java, 5) SMP Negeri 31 Purworejo, Central of Java, 6) SMP Negeri 4 Wates, Kulon Progo, Yogyakarta, 7) SMPK St. Aloysius Turi, Sleman, Yogyakarta, 8) SMP N 2 Playen Gunungkidul, Yogyakarta, 9) SMP N 2 Giriwoyo, Wonogiri, Central of Java, 10) SMPK St. Maria II Malang, East of Java, and 11) SMP St. Fransiskus Asisisi Samarinda, East of Kalimantan. Data is collected using questionnaire technique (open closed). Given its descriptive explorative nature, the data analysis is performed by quantitative percentage techniques and the data is presented in a graphical perspective.

\section{RESEARCH RESULTS}

\subsection{Teacher Attitude About the Importance of Character Education Assessment}

When asked on how important the assessment of character education at school was, the participants showed the following responses:

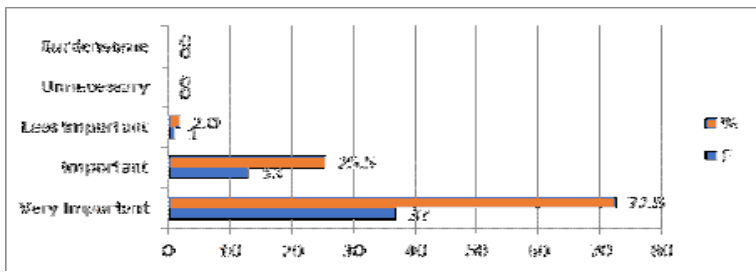

Figure 1: Teacher Attitude about the Urgency of Character Education Assessment $(\mathrm{N}=51)$

Most of the respondents (73\%) acknowledged that the character education assessment is very important, while $25 \%$ of 51 teachers considered the assessment as important and only 1 person (2\%) rated it as less important. From this perspective, the teachers have a principled awareness and understanding that character education assessment is an inherent part of the overall character education program and should be implemented.

\subsection{Implementation of The Character Education Assessment in Schools}

Answering the question of how the character education assessment in your school is implemented, 51 teachers respond as follows: 


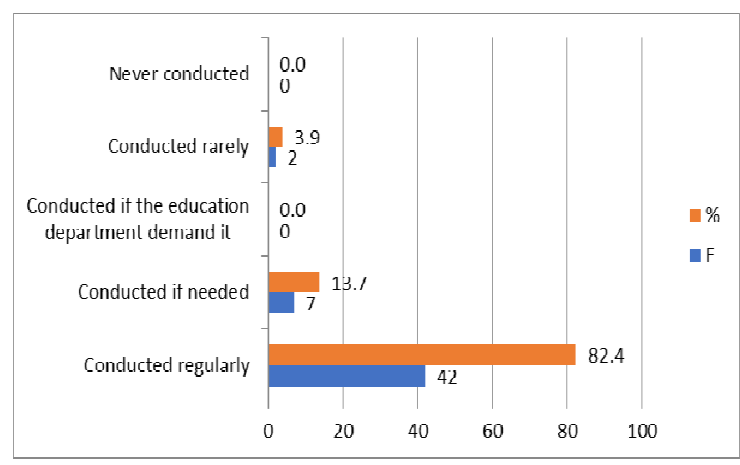

Figure 2: Implementation of Character Education Assessment

Most of the respondents (82.4\%) acknowledged that the character education assessment performed routinely in their schools, while $13.7 \%$ acknowledged that the assessment was conducted when needed and only 2 people (3.9\%) recognized the character education assessment rarely implemented. Whether the teacher's response is a real fact in the field or not, the data will reveal the truth (or lie) of this fact.

\subsection{Teachers Were Asked to Write Down the Purpose of Conducting a Character Education Assessment at Their School.}

From 51 respondents, 100 variations of mixed answers were obtained between character education objectives and character education assessment objectives. 49 answers were identified of the 100 variations of responses and only one-third (30\%) of respondents who lead to the purpose formulation (relatively appropriate) of character education assessment. Some similar formulas, generally a small fraction of teachers, understand the purpose of educational assessment that have following characteristics: 1) determine the achievement of the student's character, 2) as the initial provision of appropriate assistance, 3) evaluate the character education program that has been accomplished, 4) measure the success/effectiveness of the character education implementation, 5) determining the learners moral values and personality, 6) the results can be used to make the next planning, 7) fix the programs deficiency, 8) know the attitude and behavior of students in accordance with the Indonesian culture, 9) improve the character according to the school program, 10) obtaining feedback and become an EDS material, 11) as the base for providing further guidance to students, 12) as report material to parents/guardians on report cards, 13) assessing the extent of their activities that affecting children, 14) meet the government demands, and 15) facilitate in assessing student attitudes.

\subsection{How Does the School Design a Character Education Assessment? From 51 Participants}

The study obtained the following data:

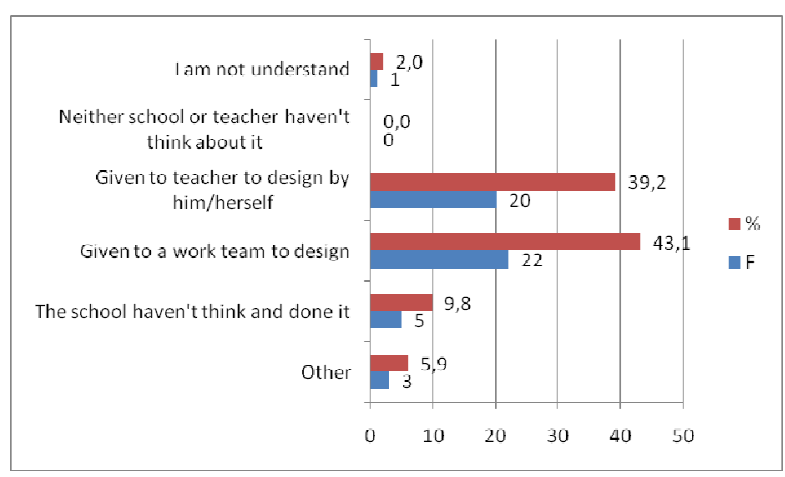

Figure 3: How School Design A Character Education Assessment

In designing/planning the character education assessment, the respondents is split into two sides. Almost half of the respondents confirmed that the task of designing a character education assessment was submitted to a work team, while nearly $40 \%$ of participants said that the assignment was assigned to each teacher

\subsection{Guidelines for The Character Education Assessment in Schools}

When asked, what the basis is used in the student character educational outcome assessment in school, the composition of the participants' responses is as follows (multi-response):

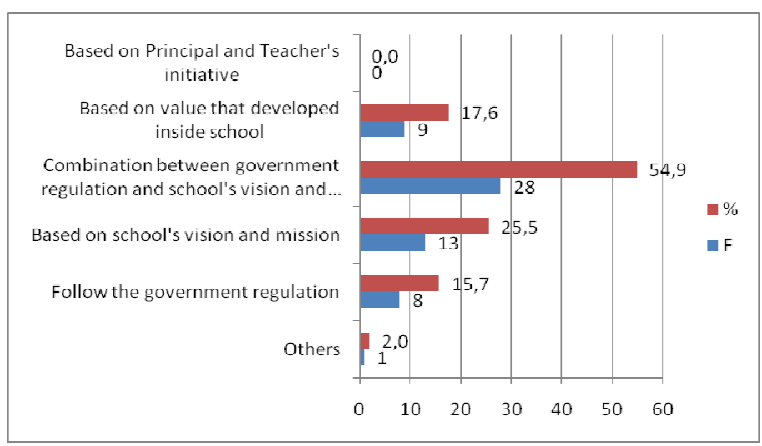

Figure 4: Guidelines Used as The Character Education Assessment Basis

Most respondents provide the normative ideal answer, which is carry out the assessment of character education outcomes based on government guidelines and the school vision and mission. 


\subsection{Teachers' Expected Goals of Character Education Assessment}

For what purposes are the character education outcomes is conducted? Participants hope that through the assessment of character education can measure/note the following (multi-response):

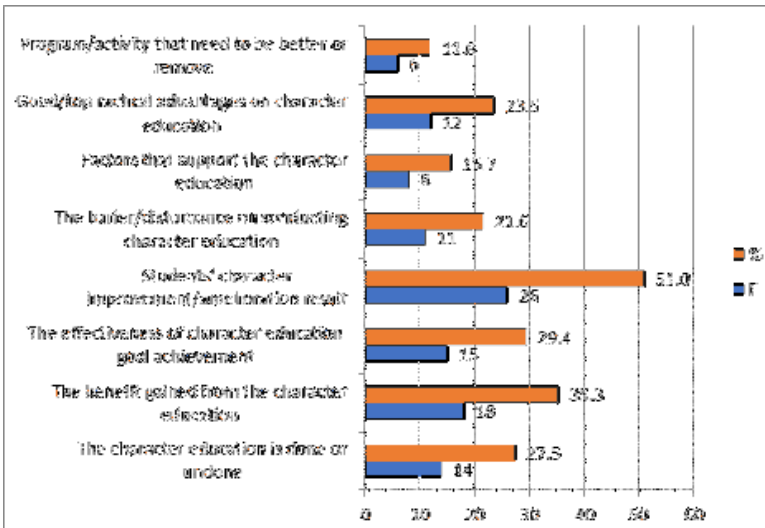

Figure 5: Goals that Teachers Expect in Character Education Assessment

The objective of character education assessment expected by most teachers is to know the improvement of the students' character and only small proportion of respondents who choose the assessment process. This fact indicates that most teachers need more information about indicators of educational attainment of student character, not on how the character education program is planned and implemented, what are the supporting and constraining factors, and program/activity follow-up.

\subsection{The most preferred aspect of the character education assessment in school according to the respondent is illustrated as follows (multi-response):}

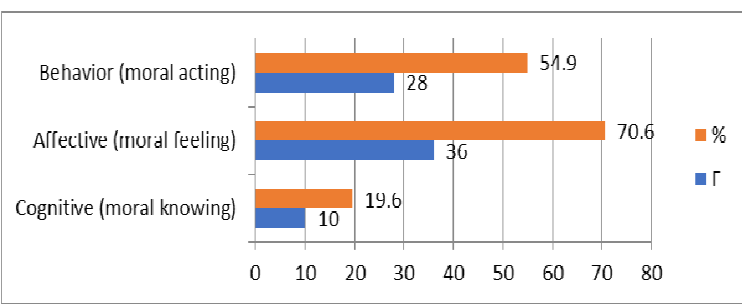

Figure 6: Preferred Assessment Aspect in Character Education Assessment

Most teachers are well aware that the character education outcomes assessment should focus on the affective aspect (moral feeling) and aspects of the action (moral acting), not just on cognitive aspects (moral knowing). This understanding is in line with the mission of character education itself, which is to build morals, character, moral behavior.

3.8 Seven general steps in the character education assessment presented to the respondents, then they are asked to choose (multi-response) which steps are done? The distribution of teachers' responses is as follows:

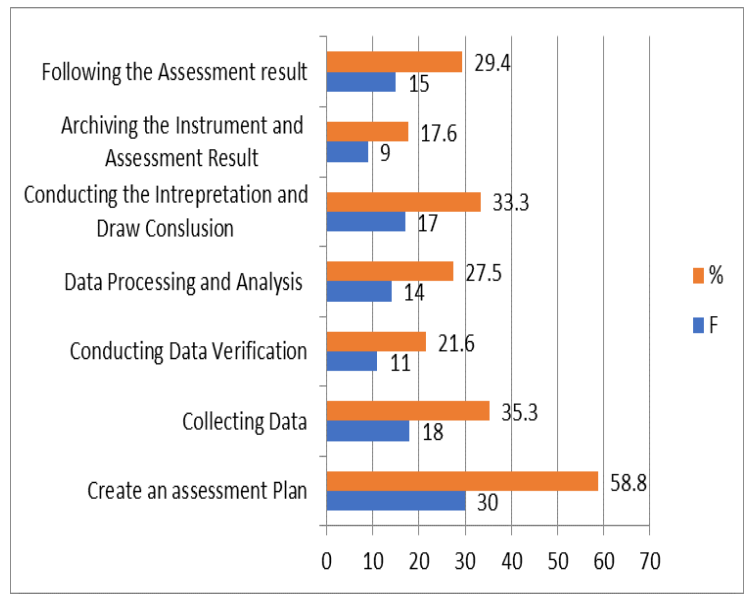

Figure 7: Step Character Education Assessment Performed

Most teachers were stopped at the planning stage (may be limited to indicating a desire/intention/willingness), and even not written, just a wishful thinking. Only one-third of the respondents reached the stage of collecting data, processing, and interpreting the character education assessment data. This fact is very counter-indicative of the data in Figure 1 where nearly $75 \%$ of teachers are aware of the assessment as important, as well as in Figure 2 where more than $80 \%$ of respondents admitted that character education assessments are routinely conducted in their schools. It turned out that this recognition gets pressure on social desirability factors. 


\subsection{The question continues, from the seven steps above, which step is felt the most difficult? The teachers' responses are distributed as follows (multiple responses):}

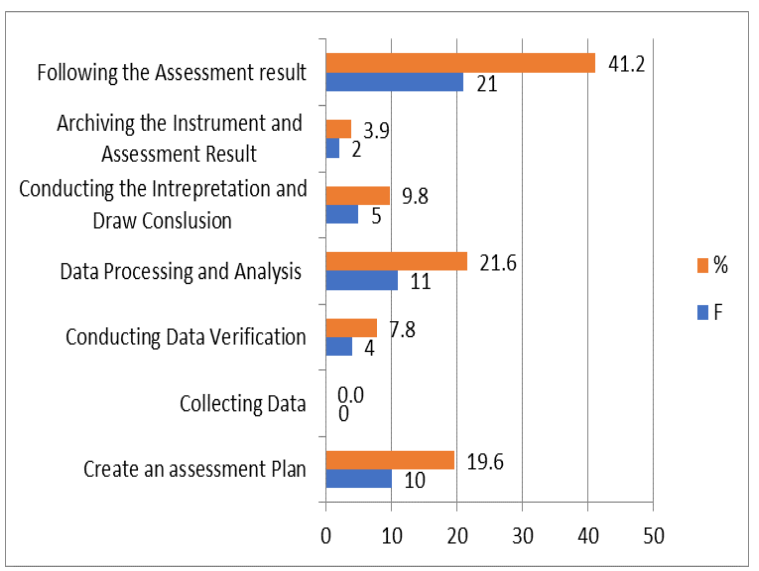

Figure 8: Most Difficult Steps in Character Education Assessment

The facts in Fig. 8 are consequential related with the data in Figure 7. Because in the implementation of the character education assessment is still limited to the plan, not yet in the step of obtaining the results data, then of course most teachers have difficulty in the follow-up stage. Logically, what is followed up, while the data does not exist, and has not reached the stage of collecting, analyzing, and interpreting data (Figure 7). Even if one arrives at the stage of collecting data, the processing may be less precise, data bias, invalid, subjective because most rely on the means of observation without tools (check the next figure)
3.10 When asked, what assessment techniques/techniques are used to assess the student's character outcomes? The teacher response is distributed as follows (multiple responses)

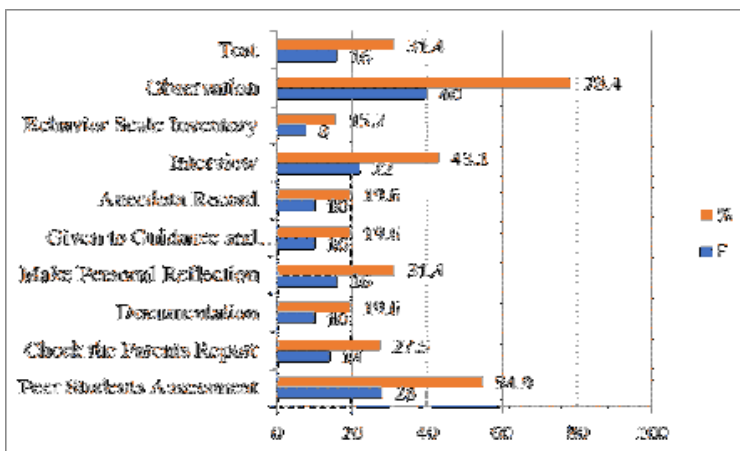

Figure 9: Techniques Used in Character Education Outcomes Assessment

There is no doubt that the most popular way teachers have in assessing character education outcomes is observation, though it is not a single way. More than half of participants admitted to applying peer assessment. Both ways can sometimes be combined with interviews, but few (15.7\%) teachers choose to inventory the attitude scale. This is understandable, because composing inventory or attitude scales is not easy for most teachers.

\subsection{When asked what are the advantages of the assessment techniques used in assessing the outcome of character education at school?}

Based on teacher's response to this opened question items, it is founded that 40 variations of respondents who favor the observation techniques. The point of excellence observation according to them were: 1) provide a directl assessment of the students character (especially problematic), 2) easy to assess, 3) easy in the processing, 4) clearer, 5) objective, 6) can be done while performing other task, 7) obtained valid data, 8) easy to know the result of character education (attitude, behavior, deed, words), 9) able to show the student personality value in the form of numbers and categories, 10) useful for follow-up mentorship, 11 ) evidence of student behavior, 12) can see, assess child learning outcomes, child attitudes, in everyday life, 13) observing student talents and trends, 14) face-to-face, $15)$ mutually supportive and complementary, 16 ) can observe and assess every moment, 17) increasingly affect the results validity, 18) know and understand 
the students well, and 19) more subjective, making them easier to evaluate.

\subsection{What are the shortcomings of the assessment techniques used in assessing the character education outcome in schools?}

Of 51 teachers who answered openly, founded 40 variations of responses that all lead to the weakness of observation that relied as characteristic assessment of character education. Identified disadvantages of assessment techniques (observations) are as follows: a) need more time $(14 \%), b)$ too many students/big class $(12 \%)$, c) less detailed and specific objects assessed $(8 \%)$, d) less orderly in documenting the assessment $(8 \%)$, less objective assessment $(6 \%), \mathrm{f})$ there is difficulty in evaluating each student's actions $(6 \%), \mathrm{g})$ the teacher forgot to record the observation result of the students because of the large number of students so that only the final observation results are traced. (4\%), h) unequal result of each teacher $(4 \%)$, i) difficult to determine attitude scale interval $(4 \%)$, j) Still doubt whether it was a valid observation or not to measure student character (4\%), k) good students are often left untouched, 1) difficult to analyze assessment results, $\mathrm{m}$ ) observations are limited to school only, n) no tests are available in order to characterize students better, o) sometimes students are dishonest in filling out the given tests, p) too many problems and too many materials needed in character education, and q) lack of understanding of the student character.

\subsection{When Asked How Often and The Duration of the Character Education Assessment Activities Were Performed}

the teacher responses spread as follows:

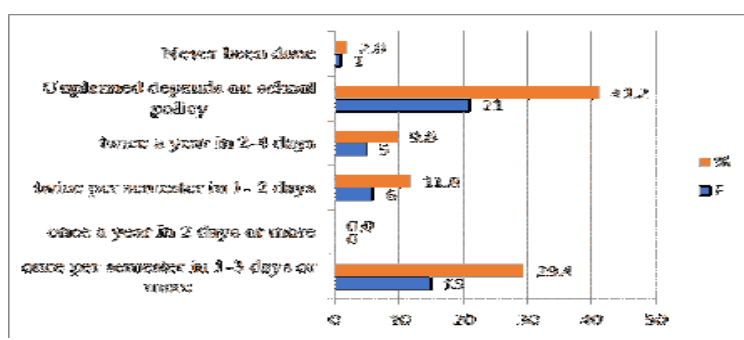

Figure 10: Frequency of Implementation of Student Character Education Result Assessment

As in the data in Figure 7, the facts in Figure 10 reinforce the indicative contra-indicative of participants who mostly say the character education assessment performed routinely (Figure 2), in fact $41.2 \%$ of respondents admitted that the character education assessment was conducted incidentally, depend on school policy. Thus, the acknowledgment of $82.4 \%$ of respondents who claimed to conduct a character education assessment on a regular basis, half of which was refuted.

\subsection{In The Case of Students' Educational Character Outcomes Is Used as A Determinant of the Class Grading.}

Most respondents agree as follows:

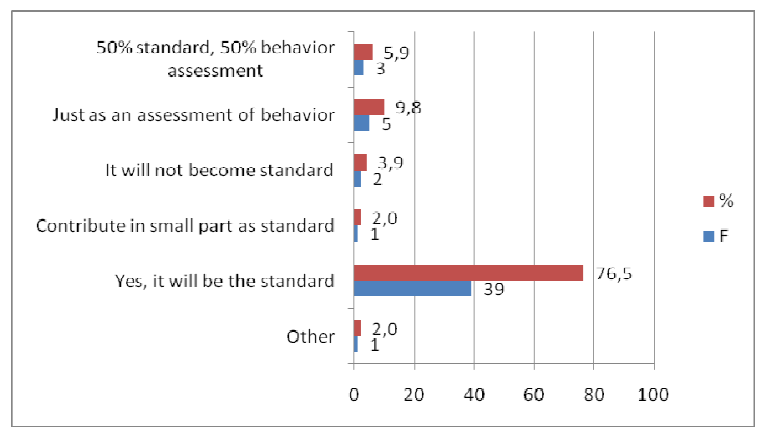

Figure 11: Result of Character Education Assessment as Criteria of Class Grading

More than one-third of teachers recognize that the results of a character education assessment become aspect in determining student classroom grading decisions. It can not be underestimated that the policy and assessment system of character education outcomes should be immediately addressed so that schools can generate measurable classroom grading decisions with objective, honest, and responsible data.

\section{DISCUSSIONS}

Most teachers have realized the important role and the need to conduct a character education assessment. This is in line with their need to obtain the necessary data in assessing the attitude/behavior/character component on the report card. They also acknowledge that they have carried out the assessment on a regular basis, although in practice it has largely ceased in the planning, dreaming, intangible phase, just as Trevisan \& Hubert (2001:227) suggested that the "remains elusive", And is an unpopular activity (Cheramine \& Sutter, in Brown \& Trusty, 2005: 177). Most teachers claim to have conducted a character education assessment routinely, but when asked how often it was done, half responded erratically depending on school policy. That is, in other part, they deny theirown recognition and inconsistency. In the meantime, only $30 \%$ of the study participants' 
teachers could formulate the objectives of a character education assessment appropriately, an indication that their knowledge of the character education assessment is minimal.

About how the school designs an assessment of character education outcome, there are two dominant groups of answers. Some said they were handed over to one working team, others said they were charged to each teacher. This policy is the root of why the character education assessment is not implemented in real terms among teachers. Although they are not anti to the assessment work, most of them do it simply, in a way, without systematic and measurable planning. Basic concepts of measurement, experimental design, and research are far from exciting to most practitioners (Shaw, in Winkel \& Sri Hastuti, 2015). Astramovich, Coker, \& Hoskins (2005:52) mentioned the obstacles, including lack of interest and ability to systematically evaluate services, lack of training opportunities in program evaluation, and lack of practical program evaluation models for teacher or counselors to utilize.

One of this study finding indicates that most teachers $(78.4 \%)$ rely on the use of observation as a means/method of student character outcomes assessment. This understanding is certainly appropriate, since character assessment should be focused on aspects of attitude measurement, moral acting. Although this method is believed by teachers to have a practical advantage and can directly catch the character behavior, but some researchers have questioned the validity of information and data obtained using this technique (Skager and Weinberg, 1971; Gay, 1987). Moreover, as many teachers have admitted, observations is more time-consuming than the use of other methods (Borg and Gall, 1989; Gall et al., 1996) and need longer time in processing/analyzing data (Borgdan and Binklen, 1982). Personal factors, such as interests, experiences, expectations, knowledge and so on, are very influential in observation.

To reduce the element of artificial behavior and assessment bias, many experts suggest the use of participant observation. However, participant observation has often been criticized as being subjective, biased, impressionistic, idiosyncratic, and lacking quantifiable measurement (Cohen and Manion, 1989). Observing people, especially without their knowledge requires ethical standard of behavior especially when recording their words and behavior (Gay, 1987; Borg and Gall, 1989; Robson, 1995). The setting and behavior of the participant may also affect by the presence of the observer (Borg and Gall, 1989). The greater the observer's participation the greater the observation may be biased (Gay, 1987; Robson, 1995).

In non-participant observation mode, teachers are not involved in the situation that being observed (Gay, 1987; Borg and Gall, 1989). Observers observe from the outside and do not interact directly with the subject. Cohen (1989) suggested that the best way for non-participant observers is to sit in the classroom and take notes of everything that happens. But the presence of observers often alters the situation observed (Gall, et al., 1996). Although reliability and validity are high it might lose its complexity and completeness because it is hard for the informants to give accurate information and act in the same manner all the time (Robson, 1995).

Although constrained by various practical, methodological, teacher's poor skill and time-limited issues in assessing the character education outcomes in more appropriate ways, they are forced by the demand to assess the students' character as one of the classroom improvement criteria. Under these circumstances, it is questionable; are teachers able to provide objective, honest, and accountable results? If they are not, then the quality of the implementation and character education assessment is increasingly neglected and the procedures used to measure the character of the students contain lies, dishonesty, and injustice. The government seems that they need to be present to be more serious on this issue.

\section{CONCLUSIONS}

Most teachers have understood and are aware of the important role of a character education assessment in school. Most of them claimed to have carried out a character education assessment routinely, but its implementation was largely limited to planning, wishful thinking. Few teachers acknowledge having reached the stage of collecting, processing, and interpreting the results of the assessment. Their acknowledgment of conducting a character education assessment on a regular basis is apparently indisputable when on the other hand they acknowledge that the frequency of its implementation is uncertain, depending on the school policy. Their responses were inconsistent. That is, the implementation of the character education outcomes assessment in 11 SMPs studied has not been as expected, still neglected, not implemented based on the principles of true affective assessment.

Only few teachers could accurately define the purpose of a character education assessment, while the remaining $(70 \%)$ defined the purpose of the assessment jumbled with the goal of character education itself. Almost half of the respondents explained that the design of the character education assessment was submitted to a work team, while the rest claimed that the responsibility was assigned to each teacher. Most teachers rely on observation as the most commonly used way of student's character assessment, although they recognize many disadvantages of using the observations. These three facts indicate that the assessment of character education in junior high school (SMP) has not been well implemented and still faced many obstacles. Nevertheless, the assessment of the students' 
character obtained by crude and untested reliability means and doubtful validity/objectivity as it is recognized by $76.5 \%$ of respondents that stated the results were used as a factor of student class degree decisions. Hardly say, this kind of work does not educate, sacrifice students, and obscure the visionmission and the purpose of the real character education.

\section{ACKNOWLEDGEMENTS}

Highly gratitude specially to the Dear Director of Research and Community Service, Directorate General of PRP, Kemristekdikti (Higher Education and Technology Ministry) who has financed the implementation of PSHP research in 2017 and produced an outcome partially described in this article. Thanks also to all ICSET 2017 committees and Reviewers Team who gave opportunity and place to share information of this small research result. I hope this study is useful.

\section{REFERENCES}

[1] Astramovich, R. L., Coker, J. K., \& Hoskins, W. J. (2005). Training school counselors in program evaluation. Professional School Counseling, 9 (1) 49-54.

[2] Bogdan, R. C. \& Biklen, S. K. (1982). Qualitative research for education: An introduction to theory and methods. Boston: Allyn and Bacon.

[3] Bohlin, K., Farmer, D., \& Ryan, K. (2003). Building character in schools resource guide. San Francisco: Jossey-Bass.

[4] Borg, W. R. \& Gall, M. D. (1989). Educational research: An introduction (5th ed.). New York: Longman.

[5] Brown, D. \& Trusty, J. (2005). Designing and leading comprehensive school counseling programs, promoting student competence and meeting student needs. USA: Thomson Brools/Cole.

[6] Cohen, L. \& Manion, L. (1989). Research methods in education (3rd ed.). London: Routledge.

[7] Didith, P. A., dkk. (2014). Asesmen anak usia dini. Yogyakarta: Graha Ilmu.

[8] Gall, M. D. et al. (1996). Educational research: An introduction. New York: Longman.

[9] Gay, L. R. (1987). Educational research: Competencies for analysis and application (3rded.). London: Merrill Publishing.

[10]Gibson, R. L. \& Mitchell, M. H. (2011). Bimbingan dan konseling. Yogyakarta: Pustaka Pelajar.
[11]Griffin, P. \& Nix, P. (1991). Educational assessment and reporting. Sydney: Harcout Brace Javanovich, Publisher.

[12] Johnson, D. W. \& Johnson, R. T. (2002). Meaningful assessment: A manageable and cooperative process. Boston: Allyn and Bacon.

[13] Kementerian Pendidikan Nasional. (2010). Panduan pendidikan karakter di sekolah menengah pertama. Direktorat Pembinaan Sekolah Menengah Pertama Ditjen Manajemen Pendidikan Dasar dan Menengah Kementerian Pendidikan Nasional. Jakarta: Kementerian Pendidikan Nasional.

[14] Kementerian Pendidikan Nasional. (2011). Panduan pelaksanaan pendidikan karakter. Badan Penelitian dan Pengembangan Pusat Kurikulum dan Perbukuan.

[15] Marzano, R., Debra. P., \& Jay, M. (1993). Assessing student outcomes: Performance assessment using the dimensions of learning. Alexandria: ASCD.

[16] McMillan, J. H. \& Schumacher, S. (2001). Research in education: A conceptual introduction (5th ed.). New York: Longman.

[17] Peraturan Menteri Pendidikan Nasional Republik Indonesia nomor 22 Tahun 2006 tentang Standar isi satuan pendidikan dasar dan menengah.

[18] Peraturan Menteri Pendidikan Nasional Republik Indonesia nomor 23 Tahun 2006 tentang Standar kompetensi lulusan.

[19] Robson, C. (1995). Real world research. Oxford: Blackwel.

[20] Samani \& Hariyanto. (2013). Konsep dan model pendidikan karakter. Bandung: Remaja Rosdakarya Offset.

[21] Setyawan, S. (2014). Evaluasi dan pengukuran pendidikan karakter. Retrieved from https:// www.academia.edu/

[22] Skager \& Weinberg. (1971). Fundamental of educational research: An introductory approach. London: Scott, Foresman and Company.

[23] Suparno, P. (2015). Pendidikan karakter di sekolah: Sebuah pengantar umum. Yogyakarta: Kanisius.

[24] Suyanto. (2010). Panduan pendidikan karakter di sekolah menengah pertama. Jakarta: Direktorat Pembinaan SMP, Ditjenmandikdasmen.

[25] Trevisan, M. S. \& Hubert, M. (2001). Implementing comprehensive guidance program evaluation support: Lessons learned. Professional School Counseling, 4 (3), 225-228.

[26]Uno, H. B. \& Koni, S. (2012). Assessment pembelajaran. Jakarta: Bumi Aksara.

[27] Winkel, W. S. \& Hastuti, S. (2015). Bimbingan dan konseling di institusi pendidikan. Jakarta: Gramedia. 